\title{
Using an Agroecological Approach to Farming Systems Research
}

\author{
K. Delate
}

\begin{abstract}
Additional IndeX words. farming systems research, organic, compost, soil quality, long-term research
SummarY. Sales of organic products reached $\$ 8$ billion in the U.S. in 2000 , continuing the nearly decadelong trend of $20 \%$ annual growth. In Iowa alone, organic production for all crops was 5265 ha (13,000 acres) in 1995 but 60,750 ha $(150,000$ acres $)$ in 1999 . Despite the growth in organic agriculture, our knowledge of organic farming systems remains limited. We have adopted a systems theory approach in our current research program at Iowa State University (ISU) to help address this gap in understanding. Systems theory holds that biological systems, such as agroecosystems, consist of integrated units of people, plants, animals, soil, insects and microorganisms, and each subsystem provides feedback to the other. In order to obtain input on research questions and experimental design, the Leopold Center for Sustainable Agriculture and ISU held six focus groups across Iowa in 1998 before long-term site establishment. Producers and agricultural professionals at the focus groups supported the need for long-term agroecological research (LTAR) sites in four distinct agroecological zones in Iowa. The goal of each LTAR is to examine the short- and long-term physical, biological, and socioeconomic effects of organic and conventional farming systems. By establishing long-term experiments, we are testing the hypothesis that longer crop rotations, typical of organic farms, provide yield stability, improve plant protection, and enhance soil health and economic benefits compared to conventional systems with shorter rotations and greater off-farm inputs. Examples of research results from two LTAR experiments in Iowa include similar pepper (Capsicum annuum) and soybean (Glycine max) yields in the conventional and organic systems. Organic systems used mechanical weed control and locally produced compost in place of synthetic fertilizers. Feedback from the local farm associations that are responsible for farm stewardship and farm finances is inherent in the LTAR process.
\end{abstract}

S ince 1985, there has been significant growth in the organic food industry, particularly in western countries (Lampkin and Padel, 1994). According to the USDA National Organic Standards Board (USDA, 1995), organic agriculture is defined as "an ecological production management system that promotes and enhances biodiversity, biological cycles, and soil biological activity. It is based on minimal use of off-farm inputs and on management practices that restore, maintain, or enhance ecological harmony. The primary goal of organic agriculture is to optimize the health and productivity of interdependent communities of soil life, plants, animals and people." Synthetic inputs (i.e., petroleum-based fertilizers, pesticides, animal hormones and antibiotics) are disallowed in organic production. Genetically modified organisms are considered synthetic materials under current federal organic certification rules (USDA, 2000). Consistent standards for products marketed as organic in the U.S. are predicted to allow the industry to pursue other growth opportunities (Organic Trade Association, 2001). 
Table 1. Yield and economic comparisons of conventional and organic farming systems.

\begin{tabular}{|c|c|c|c|}
\hline U.S. state & Year & Crops & Yields \\
\hline Pennsylvania & $1981-95$ & Soybean & $\begin{array}{l}\text { No statistical difference between conventional and organic } \\
\text { after 3-year rotation; higher in organic in drought years }\end{array}$ \\
\hline California & $1989-96$ & Tomatoes (Lycopersiocon esculentum) & No statistical difference between conventional and organic \\
\hline
\end{tabular}

${ }^{\mathrm{z} D o b b s}$ and Smolik, 1996.

'Hanson et al., 1997.

${ }^{\mathrm{x}}$ Clark et al., 1999.

${ }^{w}$ Brumfield et al., 2000 .

The U.S. organic industry continues to grow at a rate of $20 \%$ annually (Greene, 2000). Organic sales in 2000 equaled $\$ 8$ billion (Organic Trade Association, 2001). European consumers have led the demand for organic products, particularly in areas such as the Netherlands and Scandinavia. The world market for organic products is listed at $\$ 45$ billion (Zerger and Bossel, 1994). Two percent of all German farmland, $4 \%$ of Italian farmland and $10 \%$ of Austrian farmland is managed organically. The desire for nongenetically modified foods has contributed to the rise in organic food consumption. The demand for perceived cleaner food and a safe environment has led $90 \%$ of U.S. citizens to consider including organic foods in their diets (Hartman Group, 2001). Improved nutrition and taste claims are also associated with organic food consumption, but Reiners (1993) suggested that nutritional differences between organic and conventional vegetables had not been supported in the literature up to 1993. Many comparisons before this date, however, were made on crops lacking organic certification. Professional taste panels identified greater organoleptic quality in apples (Malus $\times$ domestica) grown under certified organic management (Reganold et al., 2001).

Statistics from the USDA Economic Research Service on organic production in the U.S. lag far behind those compiled for conventional agriculture. In 1995, there were 4050 organic operators farming 607,500 ha (1.5 million acres) (Greene, 2000). The Organic Farming Research Foundation placed the number of organic farmers at 10,000 in 1997 (Walz, 1999). In 1999, Iowa farmers reported 60,750 ha $(150,000$ acres) of organic production to the Iowa
Department of Agriculture and Land Stewardship (2000). This figure reflects only what is reported by those farmers who returned their survey. Additional, unreported areas are presumably under organic production. Iowa's organic production expanded 6-fold from 1996 to 1999.

Results from replicated experiments across the U.S. suggest that organic cropping systems are economically viable, particularly when producers receive certified organic premiums (Table 1). Distinct levels of management competencies of farmer-operators, however, may complicate profitability estimates. Management experience in organic agricultural operations will determine the relative success rate of the organic farming systems. The economic benefits of organic operations would also improve if credit were applied to agricultural operations that accrue benefits to society as a whole through sustainable practices (Brumfield et al., 2000).

\section{Organic farming research using systems theory and application}

Despite the growth in organic agriculture, our knowledge of the mechanisms operating in organic farming systems remains limited (Høgh-Jensen, 1998). Traditional research methods may not be suitable for the complexity of questions arising from organic farming systems research (Norgaard and Sikor, 1995; Vogtmann, 1990). We have adopted a systems theory approach to our current farming systems research program at ISU to help address these issues. Bertalanffy (1973) originally defined systems as a complex of interacting elements, called subsystems, constituting the whole. Systems theory assumes a hierarchical structure to scientific inquiry, much as ecological theory perceives biological systems to consist of integrated units (Elton, 1946). A system is defined by its relation to the environment, along with the major mechanisms operating within each subsystem. Emergent properties of the system arise at certain junctures in the inquiry process, usually at the higher agroecosystem level (Altieri, 1995). In addition to the need for hierarchical order, systems are regulated by feedback and progressive differentiationthe movement towards complex growth in a logical order (Lazlo, 1983). Systems studies often produce statements of a descriptive nature rather than reduce complex problems to single entities (Høgh-Jensen, 1998). Spedding (1979) introduced the concept of agriculture as a system, taking into account environmental feedback in relation to crop response. Farming systems research, popularized by Hildebrand (1990), Dent (1993), and others, integrated the human component with the cropping system. The emphasis in early farming systems research included a more descriptive analysis of energy and input flows into the agroecosystem, compared with the more linear approach of traditional research on yield response to input levels (Bawden, 1990). Altieri (1995) defined agroecology as the science of agroecosystems, including the physical, biological, and cultural features (socioeconomic) operating within and upon the agroecosystem. All aspects of soil quality and pest status, as affected by the farming system, are included in the agroecological analysis.

Farmers' perceptions of research questions and results are also inherent in the systems process. How these research results are incorporated in the surrounding farming community is key to the success of systems research. Chambers et al. (1989) recognized the importance of farmers as central to the research process, and described the concept of establishing research agendas based on 


\section{Economics}

Cost of production (COP) similar to conventional; organic premiums were not calculated

COP similar to conventional; organic premiums were not calculated

COP $12 \%$ lower in organic across all rotations; organic premiums were not calculated

COP 5\% higher in organic, but with organic premiums, superior economics with organic

COP higher in organic when previous crop costs (cover crops) and additional management over conventional (staking) included; net return per unit $5 \%$ to $16 \%$ higher in organic with organic premiums

farmer-identified problems.

Details on the planning process for long-term experiments, experimental design, sampling protocols, examples of research results, and farmer involvement are presented here to assist land grant universities interested in implementing similar programs. The ultimate goal of the network of scientists currently involved in long-term experiments is to improve the viability of agriculture through the development of sustainable practices.

\section{Materials and methods}

Planning through focus

GROUPS. In 1998, ISU and the Leopold Center for Sustainable Agriculture (LCSA) held a series of focus groups to help determine research priorities for organic farmers, or producers interested in beginning the 3 years of transition to organic production. A total of 60 producers, agricultural professionals, and county extension staff met with ISU Organic Program leaders in community centers in six locations across Iowa. An open discussion identified the need for increased research on transition strategies for organic production, including ideal crop rotations for specific Iowa conditions. Other research requests included crop (horticultural and agronomic) variety trials under organic management and pest management strategies for organic vegetable production. Following the focus group meetings, the LCSA supported the establishment of LTAR sites in four distinct environmental zones across Iowa. The goal of the LTAR is to examine short- and long-term physical, biological, and socioeconomic effects of organic and conventional farming systems. The following supporting factors for this type of research were identified at the focus group meetings.

- Because most farmers begin their transition into organic from conven- tional fields, and the Organic Food Production Act requires a minimum 3 -year transition from synthetic chemical to certified organic production, a minimum 3-year study was needed.

- Because organic farmers reported improvements in soil quality and plant productivity after several years of organic management, longer research trials were required to examine this effect.

- Emergent properties, and additional research questions, tend to arise as systems progress towards homeostasis (Høgh-Jensen, 1998).

Our research program revolved around two central themes, as described by Niggli and Lockeretz (1996): 1) evaluations of methods to improve organic farming systems and 2) an analysis of the underlying mechanisms in organic farming systems (systems analysis). One of the goals of a sustainable, organic farm is to replace external inputs with on-farm or locally produced inputs. For example, most organic farmers rely on crop rotations, compost or manure applications, and/or cover crops to satisfy crop nutrient requirements (Kelly, 1990). Biological, mechanical and cultural pest management techniques are employed in place of synthetic chemicals. One of the challenges of organic farming is locating adequate inputs (e.g., manure, compost, or cover crop biomass) to provide sufficient nutrients for optimal yields. In evaluating methods to improve organic farming systems, we are focussing on on-farm nutrient and pest management strategies in our long-term agroecological comparisons. Spatial and temporal variation in soil physical, chemical, and biological constituents are quantified in all LTAR plots to identify changes in soil quality, a key component of sustainable farming systems.

Because plot size will be limited, particularly in agricultural settings, by land availability and work force available to manage plots (van der Werf et al., 1997), consideration must be given to research objectives. As in ecological experiments, the greater the size of the individual plots, the greater the accuracy in determining treatment or system effects. A long-term ecological research (LTER) site, supported by the National Science Foundation across the U.S., has been dedicated to agroecosystem analysis at the Kellogg Biological Station (KBS) of Michigan State University, in Hickory Corners, Mich. One of the LTAR and LTER objectives is an examination of system effects under local farm management. Incorporating local farming practices (including the use of farm-size equipment) on large research plots is a unique trait of the LTER and Iowa LTARs. Land resources at the KBS-LTERpermit the use of l-ha (2.47acre) plots replicated four times for each treatment/system. Land availability at the Iowa agronomic LTAR allowed for 0.1 -ha (0.25-acre) plots, which are, on average, five times the typical agronomic plot size. In contrast to the KBS-LTER, the ISU-LTAR is based on the following concepts.

- Farmer involvement in establishing research goals and methods via focus groups and quarterly meetings.

- Use of local, commercial practices in research plots, wherever possible.

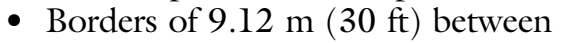
conventional and organic plots, as required for certified organic production.

- Adherence to certified organic practices and third-party certification of all organic fields.

The interdisciplinary nature of the LTAR program is reflected through the involvement of research and extension faculty, students, and staff from 10 ISU departments, a local farm association, and the county extension of- 
fice. Cooperators on the project, including Heartland Organic Marketing Cooperative and four organic seed companies, have provided materials and marketing support. Financial support for these long-term sites has been secured through grants from the LCSA, the USDA North Central Region Sustainable Agriculture Research and Education Program (SARE), and the USDA-IFAFS (Initiative for Future Agriculture and Food Systems) program. While four LTAR sites were established in Iowa, two will be discussed in this article.

LONG-TERM AGROECOLOGICAL RESEARCH SITES: Muscatine IsLand LTAR-EXPERIMENTAL DESIGN AND FIELD OPERATIONS. The 1998 Organic Focus Group identified the need for research on organically approved methods for improving soil fertility, including the efficacy of a locally produced compost and lime product for organic pepper production. Organic vegetable farmers routinely apply compost and Ca products to their soil, but there is limited research on the effects of these products. Mixed results had been reported in comparisons between compost-fertilized crops and synthetic-fertilized crops (Altieri et al., 1991; Astier, 1990; Astier et al., 1994; Lockeretz et al, 1981; Maynard, 1994; Wang et al., 1984). Inconsistent results are correlated with differences in compost application rates reported in these experiments, in addition to variable $\mathrm{N}$ content, age of compost, and weather conditions affecting $\mathrm{N}$ mineralization. Because $\mathrm{N}$ in synthetic fertilizers is rapidly mobile and available in the early phase of the growing season, slow-release organic amendments provide additional challenges for organic farmers.

In 1998, we compared the yield and fruit quality of conventionally and organically produced peppers as part of a long-term experiment at the ISU Muscatine Island Research and Demonstration Farm (MIRDF) in Fruitland, Iowa. We chose to evaluate the impact of different rates of organically approved soil amendments on crop outcomes in 1998. In subsequent years, however, we have included additional treatments and expanded our focus to include system-level effects. A staggered research design that is more amenable to new sites (van der Werf et al., 1997) will account for treatment, system, and temporal effects. Examples of research results are presented below, as an illustration of the type of agroecological data collected in systems research.

Beginning in 1999, a legume cover crop treatment [hairy vetch (Vicia villosa) and rye (Secale cereale)] was added to the LTAR fertility studies. Cover crops have been reported to increase yields when incorporated before vegetable crop planting (Altieri et al., 1991; Astier et al., 1994; Creamer, 1999; Dyck et al., 1995; Miller et al., 1989). However, $\mathrm{N}$ availability may be limited early in the season, due to immobilization after residue incorporation (Liebman and Dyck, 1993). Cover crops may be fully incorporated for nutrient management, or left as a mowed cover to help mitigate soil erosion. Leaving the mowed cover crop residue on the soil surface may also aid in weed management (Teasdale, 1993). Research in Ohio (Creamer, 1999) demonstrated comparable yields between organic tomatoes (Lycopersiocon esculentum.) planted into a mowed cover crop [hairy vetch, rye, crimson clover (Trifolium incarnatum), and barley (Hordeum vulgare)] and tomatoes fertilized with synthetic fertilizer at recommended rates. The same pattern of comparable yields between organic and synthetic fertilized crops was observed in Wisconsin (Stute and Posner, 1995) and Maryland (Lichtenberg et al., 1994) when hairy vetch was incorporated before planting.

Plots measuring $8 \times 3 \mathrm{~m}(26 \times 10$ $\mathrm{ft}$ ) were arranged in a randomized complete block design. Plots were separated by $4.6-\mathrm{m}(15-\mathrm{ft})$ borders within systems, and $9.12-\mathrm{m}(30-\mathrm{ft})$ borders separated organic and conventional plots in order to obtain organic certification. Pepper plants were transplanted mechanically at $46 \mathrm{~cm}$ within rows and $107 \mathrm{~cm}$ between rows $(18 \times$ 42 inches), to permit mechanical weed control, perlocal practices. Treatments, listed in Table 2, were replicated four times. Each replicate contained 40 plants. Treatments consisted of combinations of three certified organic soil amendment and two synthetic fertilizer combinations. The goal of the fertilization experiment was to obtain similar levels of $\mathrm{N}$ and $\mathrm{Ca}$ in the organic and conventional system. From 1998 to 2000, an Iowa-produced compost (Ultra-Gro, a turkey litter product from Circle Hill Organics,
Ellsworth, Iowa) was used in the LTAR experiment to supply $2.2 \mathrm{~N}-2.8 \mathrm{P}-$ $1.5 \mathrm{~K}$. Bio-Cal (Midwestern Bio-Ag, Blue Mounds, Wis.), a locally produced byproduct of the limestone industry used to supply $\mathrm{Ca}$, was applied alone and in combination with compost. Based on focus group advice, we applied organic fertilizers according to local organic farmers' rates of $56 \mathrm{~kg} \cdot \mathrm{ha}^{-1}$ and $112 \mathrm{~kg} \cdot \mathrm{ha}^{-1}$ (50 and $100 \mathrm{lb} /$ acre) of $\mathrm{N}$. These rates were derived by assuming $100 \%$ release of the $\mathrm{N}$ concentration reported on the label, based on local farmer practice. The cover crop was seeded in selected plots in September of the year preceding the growing season, and mowed before plow-down in the spring as one treatment, or left on the surface in the strip-tilled treatment. Tilled strips were $38 \mathrm{~cm}$ ( 15 inches) wide and spaced on $107-\mathrm{cm}$ centers.

Pest management also followed local organic practices, including monitoring for insect and disease populations before the application of any materials. Weeds were machine- or hand-cultivated throughout the season. Irrigation was applied as needed through overhead risers to supply approximately 100,000 L.ha-1 $(107,287$ gal/acre) weekly. Conventional plots were treated with Treflan herbicide at 1.2 $\mathrm{L} \cdot \mathrm{ha}^{-1}$ (1 pt/acre), according to ISU recommendations.

NeELY-KINYON LTAR-EXPERI-
MENTAL DESIGN AND FIELD OPERATıons. The Neely-Kinyon Farm Association, a farmer organization charged with management of the ISU NeelyKinyon (N-K) farm, dedicated a 7 -ha (17-acre) block of farmland for the $\mathrm{N}$ K LTAR site in Greenfield, Iowa, in 1998. In order to equalize conditions, the field was moldboard plowed, disked, and field cultivated for seedbed preparation in 1998 at the start of the experiment. Because soil analysis revealed a uniform soil type, slope, and fertility status, the forty 0.1 -ha fields were arranged in a completely randomized design. The four system treatments consisted of the local conventional system [corn (Zea mays)-soybean rotation] and three organic systems [corn-soybean-oats (Avena sativa)/alfalfa (Medicago sativa), cornsoybean-oats/alfalfa-alfalfa, and soybean-rye)]. In any given year, corn and soybean varieties were identical across organic and conventional systems. Based on local farmer advice to 
test new varieties, crop varieties were changed from year to year, but remained the same variety for the organic versus conventional comparison each year. Four replications of each system were planted. In order to account for weather variability, all crops in all rotations were planted each year. All organic systems are approved by the State of Iowa Organic Certification Program. The organic fields were certified organic in 2000, after the required 3-year period from the last application of synthetic substances. A hay crop [alfalfa, red fescue (Festuca rubra), and oats], seeded in 1998 in the $9.12-\mathrm{m}$ border strips around each plot and around the perimeter of the experiment, was periodically mowed and maintained as the required buffer between conventional and organic production, per certification standards.

Nutrients were supplied to the organic fields through the application of hoop-house compost from the local ISU Armstrong Research and Demonstration Farm (1.8N-2.8P-1.5K) and from the previous alfalfa cover crop in the third or fourth year. The compost consisted of deep-bedded swine manure mixed with corn stalks and straw, which was turned and stored for 1 year before application. Fertilization rates were adjusted in each plot, based on $\mathrm{N}$ additions from the previous crop (i.e., alfalfa), to provide about $134 \mathrm{~kg} \cdot \mathrm{ha}^{-1}$ (120 lb/acre) of N, using a calibrated, farm-size manure spreader. Conventional corn plots were fertilized with synthetic fertilizer at the same rate.

Pest management applications were made based on population densities identified during biweekly monitoring. No insecticides were required in the organic system from 1998-2000. In the conventional system, corn insecticides and herbicides were applied in all plots at preplanting, based on local practices. Mechanical tillage, with rotary hoes and row cultivators, constituted weed management in the organic system. In addition to mechanical tillage, a propane flame-burner was used in 2000 to manage weeds in the organic corn plots. Quality in tofu soybeans is equated with clean seed, free of weed seeds. Because soybeans were clear-hilum varieties for the tofu market, large weeds were removed by walking through the soybean fields on two occasions before harvest. All labor for weeding and other operations was recorded in the cost of production studies.

Sampling protocols-MuscaTINE ISLAND LTAR. A core set of measurements was taken bimonthly on 10 plants per plot (40 plants total per treatment) to assess crop biomass and plant health. Plant height and leaf number were recorded, in addition to numbers of harmful and beneficial insects. Soil was sampled by taking a composite of three $15-\mathrm{cm}$ (6-inch) cores in each plot at preseason and in the hairy vetch plots after residue decomposition, according to methods described in the agronomic LTAR below. Peppers were harvested when mature and culls (fruit with damage due to insects or disease) were separated from marketable fruit. Harvests occurred until peppers were no longer of marketable quality (average of three harvests per year over 3 years). Marketable fruit was transferred to $10^{\circ} \mathrm{C}\left(50^{\circ} \mathrm{F}\right)$ refrigerated storage in the ISU Department of Horticulture for postharvest storage-life studies. Fresh weights were taken immediately after harvest and at weekly intervals thereafter. All data were subjected to analysis of variance and mean separation (Fisher's PLSD test, $P<0.05$; SAS, 1988).

Sampling protocols-NeelyKinyon LTAR. Crop staging (number of plants per hectare) was conducted for corn and soybeans; and biomass sampling was completed on oat and alfalfa fields. Nitrate content was measured in corn stalks collected 2 weeks before harvest by the ISU Agronomy Plant Analysis Laboratory. At harvest, grain was collected from the interior eight rows of each plot, using a farmsize combine equipped with a yield monitor. Three randomly collected 200-g (0.44-lb) grain samples were collected from each plot for protein, oil and starch quality analysis at the ISU Grain Quality Laboratory. Oats were evaluated for protein content only (other analyses not available at ISU labs).

Weed populations were determined on two sampling dates by counting all weeds (broadleaves and grasses) within a $1-\mathrm{m}^{2}\left(10.8 \mathrm{ft}^{2}\right)$ quadrat at three randomly selected areas within a plot. Leafhopper populations were determined in each oats-alfalfa plot by sweeping five times with a $35-\mathrm{cm}$ (14inch) diameter net in three random areas of each plot. Insect samples were placed in zip-lock bags, kept on ice, and transported to the lab for analysis. Corn borer (Ostrinia nubilalis) populations were assessed by examining the whorl of three $1-\mathrm{m}(3.3-\mathrm{ft})$ tall plants per plot and recording presence of corn borer larvae. Soybean insects were collected (15 sweeps per plot) during the pod set period. Samples were treated as described above. Likewise, corn earworm (Helicoverpazea) populations were assessed 3 weeks before harvest by examining the ear of three plants per plot and recording presence of corn earworm larvae and damage. Four $0.5-\mathrm{L}$ (1-pt) soil cores were collected at a $15-\mathrm{cm}$ (6-inch) depth from each soybean plot. Samples were analyzed for soybean cyst nematode (Heterodera glycines) egg populations at the ISU Plant Disease Diagnostic Laboratory.

Soil samples were collected in April before spring plowing and after harvest in November of each year. Five intact $7.5-\mathrm{cm}(3$-inch) diameter soil cores were collected to a $30-\mathrm{cm}$ depth from randomly located points in each of the 40 plots at each sampling date. Each core was partitioned into 0 to $7.5,7.5$ to 15 , and 15 to $30-\mathrm{cm}(0$ to 3,3 to 6 , and 6 to 12 -inch) depth increments. The five individual cores from each plot were combined into one composite sample for each depth. Composite samples were stored in plastic zip-lock bags and kept cool during transfer to the laboratory. Bulk density, water content, soil microbial biomass $\mathrm{C}$, organic $\mathrm{C}$, particulate organic matter $\mathrm{C}$ and $\mathrm{N}$, aggregate stability, $\mathrm{N}$ mineralization potential, $\mathrm{pH}$, electrical conductivity, Mehlich extractable $\mathrm{P}, \mathrm{K}, \mathrm{Ca}, \mathrm{Mg}$, and $\mathrm{Na}$ were determined following methods used for other Iowa LTAR experiments (Cambardella, 1994; Cambardella and Elliott, 1992; Cambardella and Elliott, 1993; Delate and Cambardella, 1999).

Budgets were developed for each system, based on actual costs at the site and prices at the local organic and conventional elevators (Chase and Duffy, 1991). Costs included labor, materials, and equipment use.

EXAMPLES OF RESEARCH RESULTS-MUSCATINE ISLAND LTAR.

Pepper growth and yield were not influenced by production system (conventional or organic) in 1998 and 1999 (Delate, 1999; Delate and Lawson, 2000). Organic peppers fertilized with $112 \mathrm{~kg} \cdot \mathrm{ha}^{-1}$ of $\mathrm{N}$ from compost plus $1008 \mathrm{~kg} \cdot \mathrm{ha}^{-1}$ (900 lb/acre) Bio-Cal 
Table 2.Pepper (Capsicum annumm) harvest parameters, Muscatine Island Research and Demonstration Farm, 2000.

\begin{tabular}{|c|c|c|c|c|}
\hline Treatment & $\begin{array}{l}\text { Pepper wt/ } \\
\text { plant }(g)^{z}\end{array}$ & SE & $\begin{array}{l}\text { Mean no. of } \\
\text { culled peppers }\end{array}$ & SE \\
\hline Organic control & 375.01 & 22.18 & 0.50 & 0.29 \\
\hline Organic compost at $112 \mathrm{~kg} \cdot \mathrm{ha}^{-1}$ of $\mathrm{N}^{\mathrm{y}}$ & 576.56 & 42.98 & 1.00 & 0.41 \\
\hline Organic Bio-Cal ${ }^{\mathrm{x}}$ plus compost $\left(56 \mathrm{~kg} \cdot \mathrm{ha}^{-1} \text { of } \mathrm{N}\right)^{\mathrm{y}}$ & 489.83 & 24.60 & 0.25 & 0.25 \\
\hline Organic Bio-Cal plus compost $\left(112 \mathrm{~kg} \cdot \mathrm{ha}^{-1}\right.$ of $\left.\mathrm{N}\right)$ & 500.67 & 51.12 & 0.75 & 0.48 \\
\hline Hairy vetch tilled & 421.97 & 65.97 & 0 & 0 \\
\hline Hairy vetch strip-tilled & 116.77 & 17.58 & 0 & 0 \\
\hline Conventional control & 398.72 & 23.18 & 2.50 & 0.87 \\
\hline Conventional fertilizer & 589.16 & 89.06 & 5.25 & 1.44 \\
\hline Conventional fertilizer and lime & 638.64 & 65.75 & 1.75 & 0.75 \\
\hline $\mathrm{LSD}_{0.05}$ & & 15.15 & & 1.91 \\
\hline
\end{tabular}

${ }^{\mathrm{z}} 454 \mathrm{~g}=1 \mathrm{lb}$.

y $112 \mathrm{~kg} \cdot \mathrm{ha}^{-1}=100 \mathrm{lb} /$ acre; $56 \mathrm{~kg} \cdot \mathrm{ha}^{-1} \mathrm{~N}=50 \mathrm{lb} /$ acre.

${ }^{x}$ BioCal calcium amendment (Midwestern Bio-Ag, Blue Mounds, Wis.).

had similar biomass and yield values compared to conventional peppers. The hairy vetch/rye cover crop in our 1999 experiments provided $100 \%$ cover and an estimated $137 \mathrm{mg} \cdot \mathrm{kg}^{-1}(\mathrm{ppm})$ of $\mathrm{N}$ to the soil. Yield in plots where hairy vetch was incorporated was equivalent to yield obtained in the 112 $\mathrm{kg} \cdot \mathrm{ha}^{-1}$ of $\mathrm{N}$ compost treatment, but less than the plots receiving compost plus Bio-Cal. There were no significant yield differences in 1999 between plots where hairy vetch was completely incorporated into the soil versus striptilled. Hairy vetch growth in Fall 1999Spring 2000 was impacted by hot and dry weather conditions. Stands were less than $50 \%$ in $75 \%$ of the plots in 2000 (Delate and Lawson, 2001). Poor hairy vetch growth contributed to lower yields in these treatments compared to previous years. In 2000, plants fertilized with $112 \mathrm{~kg} \cdot \mathrm{ha}^{-1}$ of $\mathrm{N}$ compost produced equivalent yields to those receiving conventional fertilizer without lime (Table 2).

Some damage was present on harvested fruit despite noneconomical insect and disease population levels from 1998-2000. The number of culled peppers due to insect or disease damage was similar in conventional and organic plots in 1998 and 1999. In 2000 , however, a greater number of culled peppers did occur in the conventional plots at the first harvest $(P<$ 0.05 ) (Table 2). Conventional production also resulted in a greater number of culled fruit after 3 weeks in storage in 2000 (Table 2).

Numbers of pepper insect pests (corn borer larvae) and beneficial insects [ladybeetles (Coccinella septempunctata), lacewings (Chrysoperla carnea) and spiders (predominantly Salticidae)] were recorded in the LTAR experiment. From 1998 to 2000 , there were no significant differences in insect populations, including the most predominant beneficial insect, spiders (Table 3). Insecticide application is a routine practice in conventional pepper production in Iowa. In future years, if economic thresholds are exceeded and insecticides are applied in the conventional plots, more beneficial insects may be found in the organic plots (Altieri, 1995). A detailed economic analysis will be conducted beginning in 2001 with the initiation of the USDA Organic Agriculture Consortium research and extension project. The Consortium involves five U.S. institutions, including ISU and North Carolina State University who will coordinate the economic analyses. In the 3 years of the ISU vegetable system LTAR research, local market prices for organic peppers averaged $70 \%$ above conventional prices.

EXAMPLes OF RESEARCH RESUlts-NeELY-Kinyon LTAR. Firstyear results (1998) from the N-KLTAR site were very encouraging. Yields in the organic and conventional corn and soybean plots were similar (Delate and Cambardella, 1999). Conventional corn averaged $8.9 \mathrm{Mg} \cdot \mathrm{ha}^{-1}$ [169 bushels/ acre ( 1 bushel of corn $=47.3 \mathrm{lb})]$ while organic corn averaged $7.4 \mathrm{Mg} \cdot \mathrm{ha}^{-1}(140$ bushels/acre). Yields in the organic corn plots were strongly influenced by the previous crop (alfalfa vs. soybean), with organic corn yield greatest at 9.4 $\mathrm{Mg} \cdot \mathrm{ha}^{-1}$ (177 bushels/acre) following alfalfa. Average conventional soybean yields of $2.8 \mathrm{Mg} \cdot \mathrm{ha}^{-1}$ [48 bushels/acre ( 1 bushel of soybeans $=52.2 \mathrm{lb}$ )] were similar to organic yields of $2.9 \mathrm{Mg} \cdot \mathrm{ha}^{-1}$ (50 bushels/acre) for organic soybeans. Organic oat grain yields averaged 1.5 $\mathrm{Mg} \cdot \mathrm{ha}^{-1}$ (4l bushels/acre). Organic oats were sold as feed with a high protein content (14.5\%). A greater premium could be realized for foodgrade oats, but excessive rainfall reduced oat test weight to below foodgrade.

Although greater in the organic corn system, weed populations apparently did not impact corn yields. Patchiness in the distribution of weeds may

Table 3. Beneficial insect populations over one season, Muscatine Island Research and Demonstration Farm, 2000.

\begin{tabular}{|c|c|c|}
\hline Treatment & Mean spider population & SE \\
\hline Organic control & 1.00 & 0.70 \\
\hline Organic compost at $112 \mathrm{~kg} \cdot \mathrm{ha}^{-1}$ of $\mathrm{N}^{\mathrm{z}}$ & 0.50 & 0.50 \\
\hline Organic Bio-Cal ${ }^{\mathrm{y}}$ plus compost $\left(56 \mathrm{~kg} \cdot \mathrm{ha}^{-1} \text { of } \mathrm{N}\right)^{\mathrm{z}}$ & 1.00 & 0.70 \\
\hline Organic Bio-Cal plus compost (112 kg.ha ${ }^{-1}$ of $\left.\mathrm{N}\right)$ & 0.50 & 0.50 \\
\hline Hairy vetch tilled & 1.50 & 0.90 \\
\hline Hairy vetch strip-tilled & 0 & 0 \\
\hline Conventional control & 1.00 & 0.70 \\
\hline Conventional fertilizer & 0.50 & 0.50 \\
\hline Conventional fertilizer and lime & 0 & 0 \\
\hline $\mathrm{LSD}_{0.05}$ & & NS \\
\hline
\end{tabular}


Table 4. Organic versus conventional yields at the Neely-Kinyon Farm, 1998-2000.

\begin{tabular}{|c|c|c|c|}
\hline \multirow[b]{2}{*}{ Crop } & \multicolumn{3}{|c|}{ Yield $\left(M g \cdot h a^{-1} \pm S E\right)^{z}$} \\
\hline & 1998 & 1999 & 2000 \\
\hline Conventional corn (Zea mays) & $8.9 \pm 0.2$ & $8.5 \pm 0.1$ & $7.4 \pm 0.1$ \\
\hline Conventional soybean (Glycine max) & $2.8 \pm 0.1$ & $2.8 \pm 0.1$ & $2.3 \pm 0.1$ \\
\hline Organic soybean & $2.9 \pm 0.1$ & $2.7 \pm 0.1$ & $2.1 \pm 0.1$ \\
\hline
\end{tabular}

${ }^{\mathrm{z}} 1.0 \mathrm{Mg} \cdot \mathrm{ha}^{-1}=892 \mathrm{lb} / \mathrm{acre} ; \mathrm{l}$ bushel of corn $=47.3 \mathrm{lb} ; \mathrm{l}$ bushel of soybeans $=52.2 \mathrm{lb}$.

have contributed to the absence of significant differences between organic and conventional corn plots. Organic and conventional soybean plots contained similar levels of weeds, requiring an average of $5 \mathrm{~h} \cdot \mathrm{ha}^{-1}(2 \mathrm{~h} / \mathrm{acre})$ to walk (removing only tall plants above the crop canopy) soybean plots before harvest. This corresponded with the average time organic farmers in the area spend on hand-weeding high value soybeans. Damage from corn borer larvae was insignificant and did not reach the economic threshold (5\%) required to justify spraying with Bacillus thuringiensis. Soybean cyst nematode egg populations were below economic thresholds, not uniformly distributed, and were similar among systems. Soybean grain quality analysis (protein, oil and fiber) demonstrated high values overall, and there were no significant differences between conventional and organic systems.

Second-year results from the NeelyKinyon LTAR site (Delate and
Cambardella, 2000) were also very encouraging for organic soybean production. As seen in the first year production, there were no significant differences between the organic and conventional soybeans that averaged $2.8 \mathrm{Mg} \cdot \mathrm{ha}^{-1}(47$ bushels/acre) $(P<0.05)$. Because of the wet weather, mechanical cultivation for weed control did not occur under appropriate conditions in the early growing season, which particularly affected organic corn survival and yields. A new corn variety (white milling corn) and wet weather caused an organic corn yield averaging $6.4 \mathrm{Mg} \cdot \mathrm{ha}^{-1}$ (12l bushels/acre) compared with conventional corn at $8.5 \mathrm{Mg} \cdot \mathrm{ha}^{-1}$ ( 161 bushels/acre). There were no significant differences in corn and soybean grain quality between conventional and organic treatments. Soybean protein levels in 1999 (41\%) were slightly greater than the 1998 average of $39 \%$. Organic oat yields averaged 3.1 Mg.ha-1 (85 bushels/acre) with a protein content of $12.4 \%$.

Weed populations were signifi- cantly greater in the organic corn system. Weed populations in organic soybean plots, however, were not significantly different than the conventional plots. Weed populations in the organic soybean plots did not significantly impact yields. As in 1998, broadleaf weeds predominated in both systems. Corn earworm larvae were detected at low levels in the milling corn. Although slightly lower populations were observed in the organic corn plots, differences were not statistically significant. Soybean cyst nematode (SCN) populations were again observed in 1999, but levels were below economic injury levels. Population shifts occurred from 1998, however, with the lowest number of SCN eggs detected in the conventional soybean plots (previously in corn in 1998). With the required crop rotation of soybean alternating with corn or a small grain, $\mathrm{SCN}$ populations are expected to remain low. Stalk nitrate content at the end of the season was significantly greater in the

Table 5. Soybean (Glycine max) economic analysis, Iowa State University Neely-Kinyon Farm, 1998.

\begin{tabular}{|c|c|c|}
\hline \multirow{2}{*}{$\begin{array}{l}\text { Production costs } \\
{\left[\text { actual cost }(\$ / h a)^{z}\right]}\end{array}$} & \multicolumn{2}{|c|}{ System } \\
\hline & Organic & Conventional \\
\hline Moldboard plowing & $\$ 20.01$ & $\$ 20.01$ \\
\hline Field cultivation (preplant) & $\$ 9.88$ & $\$ 9.88$ \\
\hline Fertilization & 0 & 0 \\
\hline Planting & $\$ 22.23$ & $\$ 22.23$ \\
\hline Sprayer & 0 & $\$ 6.18$ \\
\hline Rotary hoeing $(2 \mathrm{x})$ & $\$ 9.88$ & $\$ 9.88$ \\
\hline Row cultivating $(2 \mathrm{x})$ & $\$ 17.29$ & $\$ 17.29$ \\
\hline Hand-weeding & $\$ 34.58$ & $\$ 34.58$ \\
\hline Combining & $\$ 51.87$ & $\$ 51.87$ \\
\hline Hauling grain to market & 0 (free on board per contract) & $\$ 7.41$ \\
\hline & Excluding price of land & Excluding price of land \\
\hline Organic returns over conventional & $368 \%$ & \\
\hline
\end{tabular}

$\mathrm{Z}_{\$ 2.47 / \mathrm{ha}=1.00 / \text { acre. }}$

${ }^{\mathrm{y}} 1.0 \mathrm{Mg} \cdot \mathrm{ha}^{-1}=892 \mathrm{lb} / \mathrm{acre} ; \mathrm{l}$ bushel of soybeans $=52.2 \mathrm{lb}$. 
conventional system, with some plots exceeding the recommended nitrate levels.

In 2000, the year the N-K Farm became certified organic, organic corn yields exceeded conventional corn yields (Table 4 ) with feed corn yields of $7.4 \mathrm{Mg} \cdot \mathrm{ha}^{-1}$ (14l bushels/acre) in conventional plots and $7.6 \mathrm{Mg} \cdot \mathrm{ha}^{-1}$ (144 bushels/acre) in organic plots (Delate and Cambardella, 2001). Soybean yields were similar in both systems: $2.2 \mathrm{Mg} \cdot \mathrm{ha}^{-1}$ (40 bushels/acre) for conventional and $2.1 \mathrm{Mg} \cdot \mathrm{ha}^{-1}$ (37 bushels/acre) for organic plots.

SoIL QUALITY. Soil samples were analyzed on a per-plot basis and a systems basis. After one growing season (1998), summing over organic and conventional systems, the following indicators of soil quality were greater in the organic system: microbial biomass C was 228\% greater; maggroaggregate stability was $15 \%$ greater; organic C was $6 \%$ greater; particulate organic matter was C $8 \%$ greater; and $\mathrm{N}$ mineralization potential was $7 \%$ greater. Nitrate-N, a potential pollutant in Iowa waterways and groundwater, was $44 \%$ greater in the conventional system, as reflected in the excess corn stalk nitrate in some plots.

Economical analysis. Cost of production estimates, based on actual costs incurred in the project, are presented in Table 5 for LTAR soybean plots. Selling prices for organic crops represented actual 1998 prices at the local Greenfield, Iowa elevator (conventional crops) or through Heartland Organic Marketing Cooperative (HOMC, Stuart, Iowa) for the certified organic grain (HOMC, personal communication). Total costs for organic soybean production for 1998 were $\$ 253.77 /$ ha $(\$ 102.70 /$ acre $)$, excluding costs of land, with returns for 1998 organic prices at $\$ 2099.50 /$ ha ( $\$ 850.00 /$ acre), yielding a net profit per acre of $\$ 1845.83 /$ ha $(\$ 747.30 /$ acre). This profit was $368 \%$ greater than that returned on the conventional soybeans. Prices reflect the price obtainable for certified organic crops.

\section{Discussion}

Successful long-term cropping systems experiments involve multiple considerations, including long-term land tenure, skilled management, multidisciplinary examinations, and community involvement. Focus groups in Iowa determined the need for longterm experiments comparing the productivity and environmental effects of organic and conventional systems. Because organic agriculture requires a systems approach of more complexity than conventional systems (Brumfield et al., 2000), experiments comparing organic and conventional systems require a long-term plan. A strong correlation has been observed between productivity of organic systems and years under organic management (Lockeretz et al., 1981). Thus, a 6-year experiment is the minimum duration required to cover one full crop rotation cycle plus the transition period of 3 years (Stanhill, 1990). ISU's LTAR program is supported by a long-term commitment from the College of $\mathrm{Ag}$ riculture administration, the LCSA, the USDA-IFAFS and SARE programs, and community organizations. The involvement of 10 academic departments in areas of experimental design, data collection and analysis, and interpretation of research results strengthens this program.

Results from the first 3 years at the ISU LTAR sites have been very promising in terms of crop performance in organic systems and farming community support. The first year of transition to organic production is often considered the most challenging. Lower yields in the first 2 years of transition from conventional to organic production have been reported, followed by yields similar to conventional production (Brusko, 1989; Liebhardt et al., 1989; MacRae et al. 1993). However, in the first 3 years of production in the LTAR project, a transition effect was not apparent. Yields in the organic and conventional soybean plots were similar in all 3 years of transition. Organic corn yields were similar to conventional yields in 2 of the 3 years of transition, and greatest following 2 years of alfalfa. Organic pepper yields were also similar to conventional peppers when compost was applied to organic plots.

One of the primary goals of the LTAR organic sites is the establishment of a self-regulating farm with a closed nutrient cycling system. Progressive differentiation in the LTAR system has been expressed through increased soil microbial populations associated with higher organic matter cycling in the more complex organic systems. LTAR organic systems rely on locally produced compost and leguminous hay crops for improving soil fertility and plant health. Soil quality is an important component of organic production (Wander et al., 1994), as was observed in the Neely-Kinyon LTAR organic plots. Other studies have implicated adequate $\mathrm{N}$ from leguminous crops and timely weed management as requirements for successful organic systems (Temple et al., 1994). It is anticipated that soil quality will improve over time in the organic systems where longer crop rotations, and additions of organic matter from compost and cover crops, occur. An additional measurement in our staggered research design will include water quality, as greater reliance on more slowly released nutrients from organic soil amendments is expected to lead to a reduced nitrate and phosphate profile compared to conventional systems.

As rotational effects occur, we expect to see greater differences between systems in terms of nematode, weed, insect and disease populations. These effects include less soybean cyst nematode pressure in soybeans when nonhost plants, such as small grains, are included in the rotation. Incorporating small grains and leguminous cover crops in the rotation has also been shown to mitigate weed establishment (Liebman and Dyck, 1993). Emergent properties observed in the 3-year transition period include lower weed pressure in fields with longer rotations. Additional data that will be collected in future years includes shifts in weed population biomass and species composition as systems mature.

The elimination of synthetic pesticides in organic fields has resulted in increased beneficial insects and lower incidence of insect pests and plant damage (Altieri, 1995). This effect was evident in the LTAR vegetable organic site where less insect and disease damage was observed on organic peppers. Lower numbers of culled fruit in organic plots have been reported in other organic horticultural systems (Brumfield et al., 1993; Hasey et al., 1997).

Economical services provided through the longer crop rotations in the organic systems include lower inputs and subsequent lower costs of production. Consumers pay an average of $57 \%$ over conventional prices for organic products, with varying premiums paid to producers, depending 
on supply and demand (Bourne, 1999). Organic premiums in Iowa range from $20 \%$ to $400 \%$, depending on the crop and its availability (Delate and DeWitt, 1999). The greater price premium obtained for certified organic crops should offset any reduction in yields with organic systems. As an example, when organic milling corn yields were lower than conventional milling corn in the LTAR organic plots in 1999, a $\$ 93.20 / \mathrm{Mg}(\$ 2.00 /$ bushel $)$ premium for the organic corn compensated for the decrease in yield (Delate and Cambardella, 2000). Greater returns for organic corn and soybeans have been consistent in 3 years of LTAR comparisons. An economic analysis of organic and conventional vegetables will be added to the Muscatine Island LTAR system analysis in 2001.

Finally, an assessment of community benefits (e.g., changes in farm income when farmers in the area transition to organic production) will be conducted in the sixth year of the project. This long-term agroecological systems approach should yield answers to questions of not only crop performance and return on investment, but also provide insight into the "health and productivity of interdependent communities of soil life, plants, animals and people" (USDA, 1995).

\section{Literature cited}

Altieri, M.A. 1995. Agroecology. Westview Press, Boulder, Colo.

Altieri, M.A., J. Trujillo, M. Astier, P Gersper, and W. Bakx. 1991. Low-input technology proves viable for limited-resources farmers in Salinas Valley. Calif. Agr. 45:20-22.

Astier, M. 1990. Developing low-input energy saving vegetable cropping systems for small farmers in Salinas Valley. Assn. Community Based Education, Wash., D.C.

Astier, M., P.L. Gersper, and M. Buchanan. 1994. Combining legumes and compost: A viable alternative for farmers in conversion to organic agriculture. Compost Sci. Utilization 2:80-87.

Bawden, R.J. 1990. Of agriculture and systems agriculture: Systems methodologies in agricultural education, p. 305-323. In: J.G.W. Jones and P.R. Street (eds.). Systems theory applied to agriculture and the food chain. Elsevier Applied Science, London.

Bertalanffy, L. 1973. General systems theory: Foundations, developments, applications. $4^{\text {th }}$ ed. G. Braziller, New York.
Bourne, J. 1999. The organic revolution. Audubon (March-April):64-70.

Brumfield, R.G., F.E. Adelaja, and S. Reiners. 1993. Economic analysis of three tomato systems. Acta Hort. 340:255-260.

Brumfield, R.G., A. Rimal, and S. Reiners. 2000. Comparative cost analyses of conventional, integrated crop management, and organic methods. HortTechnology 10(4):785-793.

Brusko, M. 1989. What really happens when you cut chemicals. New Farm (May/ June):19.

Cambardella, C.A. 1994. Temporal dynamics of particulate organic matter $\mathrm{N}$ and soil nitrate $\mathrm{N}$ with and without an oat cover crop. Bul. Ecol. Soc. Amer. 75:30.

Cambardella, C.A. and E.T. Elliott. 1992. Particulate organic matter changes across a grassland cultivation sequence. Soil Sci. Soc. Amer. J. 56:777-783.

Cambardella, C.A. and E.T. Elliott. 1993. Carbon and nitrogen distribution in aggregates from cultivated and native grassland soils. Soil Sci. Soc. Amer. J. 57:10711076.

Chambers, R., A. Pacey, and L.A. Thrupp. 1989. Farmer first: Farmer innovation and agricultural research. Intermediate Technol. Publ., Bootstrap Press, New York.

Chase, C. and M. Duffy. 1991. An economic comparison of conventional and reduced-chemical farming systems in Iowa. Amer. J. Alt. Agr. 6(4):168-173.

Clark, S., K. Klonsky, P. Livingston, and S. Temple. 1999. Crop-yield and economic comparisons of organic, low-input, and conventional farming systems in California's Sacramento Valley. Amer. J. Alt. Agr. 14(3):109-121.

Creamer, N.G. 1999. An evaluation of summer cover crops as weed suppressive mulches in vegetables. Organic Farming Res. Found. Bul. 6:14-16.

Delate, K.M. 1999. Evaluation of organic soil amendments for certified organic pepper production. Annu. Fruit Veg. Progr. Rpt. 1998. Iowa State University, Ames.

Delate, K.M. and C. Cambardella. 1999. Comparison of organic and conventional rotations at the Neely-Kinyon Long-Term Agroecological Research (LTAR) siteFirst year results. Iowa State Univ. Armstrong Res. Demonstration Farm Progr. Rpt., Iowa State Univ., Ames.

Delate, K.M. and C. Cambardella. 2000. Comparison of organic and conventional rotations at the Neely-Kinyon Long-Term Agroecological Research (LTAR) siteSecond year results. Iowa State Univ. Armstrong Res. Demonstration Farm
Progr. Rpt., Iowa State Univ., Ames.

Delate, K.M. and C. Cambardella. 2001. Comparison of organic and conventional rotations at the Neely-Kinyon Long-Term Agroecological Research (LTAR) siteThird year results. Iowa State Univ. Armstrong Res. Demonstration Farm Progr. Rpt., Iowa State Univ., Ames.

Delate, K.M. and J. DeWitt. 1999. Organic focus groups in Iowa. Leopold Ctr. Sustainable Agr. Annu. Rpt., Iowa State Univ., Ames.

Delate, K.M. and V. Lawson. 2000. Evaluation of organic soil amendments and cover crops for certified organic pepper production. Iowa State Univ., Ames, Coop. Ext. Serv. Annu. Fruit Veg. Progress Rpt. 1999.

Delate, K.M. and V. Lawson. 2001. Evaluation of organic soil amendments and cover crops for certified organic pepper production. Iowa State Univ., Ames, Coop. Ext. Serv. Annu. Fruit Veg. Progress Rpt. 2000.

Dent, J.B. 1993. Potential for systems simulation in farming systems research, $p$. 325-339. In: F.W.T. Penning de Vries, P. Teng, and K. Metselar (eds.). System approaches for agricultural development. Kluwer Academic Publishers, Germany.

Dobbs, T.L. and J.D. Smolik. 1996. Productivity and profitability of conventional and alternative farming systems: A longterm on-farm paired comparison. J. Sustainable Agr. 9(1):63-79.

Dyck, E., M. Liebman, and M.S. Erich. 1995. Crop-weed interference as influenced by a leguminous or synthetic fertilizer nitrogen source: I. Doublecropping experiments with crimson clover, sweet corn, and lambsquarters. Agr. Ecosyst. Environ. 56:93-108.

Elton, C.S. 1946. Competition and the structure of ecological communities. J. Animal Ecol. 15:54-68.

Greene, C. 2000. Organic agriculture gaining ground. Agr. Outlook (April):9-14.

Hanson, J.C., E. Lichtenberg, and S.E. Peters. 1997. Organic versus conventional grain prodution in the mid-Atlantic: An economic and farming system overview. Amer. J. Alt. Agr. 12(1):2-9.

Hartman Group. 2001. Natural sensibility, typlification of the new wellness consumer.vol. 3(2). Hartman Group, Bellevue, Wash.

Hasey, J.K., R.S. Johnson, R.D. Meyer, and K. Klonsky. 1997. An organic versus a conventional farming system in kiwifruit. Acta Hort. 1:223-228.

Hildebrand, P.E. 1990. Farming systems research-Extension, p. 131-143. In: J.G.W. Jones and P.R. Sprent (eds.). Systems theory applied to agriculture and the 
food chain. Elsevier, London.

Høgh-Jensen, H. 1998. Systems theory as a scientific approach towards organic farming. Biol. Agr. Hort. 16:37-52.

Iowa Dept. of Agriculture and Land Stewardship. 2000. Annual survey on organic production. Iowa Dept. Agr. Land Stewardship, Des Moines.

Kelly, W.C. 1990. Minimal use of synthetic fertilizers in vegetable production. HortScience 25:168-169.

Lampkin, N.H. and S. Padel. 1994. Organic farming and agricultural policy in Western Europe: An overview, p. 437454. In: P. Midmore and N.H. Lampkin (eds.). The economics of organic farming: An international perspective. CAB Intl., Wallingford, U.K.

Laszlo, E. 1983. Systems science and world order. Pergamon Press, New York.

Lichtenberg, E., J.C. Hanson, A.M. Decker, and A.J. Clark. 1994. Profitability of legume cover crops in the mid-Atlantic region. J. Soil Water Conserv. 49:582585 .

Liebhardt, W.C., R.W. Andrews, M.N. Culik, R.R. Harwood, R.R. Janke, J.K. Radke, and S.L. Rieger-Schwartz. 1989. Crop production during conversion from conventional tolow-input methods. Agron. J. 81:150-159.

Liebman, M. and E. Dyck. 1993. Crop rotation and intercropping as strategies for weed management. Ecol. Appl. 3:92-122.

Lockeretz, W., G. Shearer, and D.H. Kohl. 1981. Organic farming in the corn belt. Science 211:540-547.

MacRae, R.J., S.B. Hill, G.R. Mehuys, and J. Henning. 1993. Farm-scale agronomic and economic conversion from conventional to sustainable agriculture. Adv. Agron. 43:155-198.

Maynard, A.A. 1994. Sustained vegetable production for three years using composted animal manures. Compost Sci. Utilization 2:88-96

Miller, P.R., W.L. Graves, W.A. Williams, and B.A. Madson. 1989. Covercrops for California agriculture. Univ. Calif. Div. Agr. Natural Resources, Davis.

Niggli, U. and W. Lockeretz. 1996. Development of research in organic farming, $p$. 9-23. In: Fundamentals of organic agriculture. Intl. Fed. Org. Agr. Movements, Tholey-Theley, Germany.

Norgaard, R.B. and T.O. Sikor. 1995. The methodology and practice of agroecology, p. 21-40. In: M. Altieri (ed.). Agroecology. Westview Press, Boulder, Colo.

Organic Trade Association. 2001. OTA newsletter. Org. Trade Assn., Greenfield, Mass.

Reganold, J.P., J.D. Glover, P.K. Andrews, and H.R. Hinman. 2001. Sustainability of three apple production systems. Nature 410:926-929.

Reiners, S. 1993. Nutritional quality of organically grown vegetables. HortTechnology 3(3):363.

SAS Institute. 1988. SAS procedures guide. SAS Inst., Cary, N.C.

Spedding, C.R. 1979. An introduction to agricultural systems. Elsevier Appl. Scie. Publ., New York.

Stanhill, G. 1990. The comparative productivity of organic agriculture. Agr. Ecosyst. Environ. 30:1-26.

Stute, J.K. and J.L. Posner. 1995. Legume cover crops as a nitrogen source for corn in an oat-corn rotation. J. Prod. Agr. 8:385390 .

Teasdale, J.R. 1993. Interaction of light, soil moisture and temperature with weed suppression by hairy vetch residue. Weed Sci. 4l:46-51.
Temple, S.R., O.A. Somasco, M. Kirk, and D. Friedman. 1994. Conventional, lowinput, and organic farming systems compared. Calif. Agr. 48:14-19.

U.S. Department of Agriculture. 1995. National Organic Standards Board annual meeting, April 1995. USDA Natl. Org. Standards Board, Wash., D.C.

U.S. Department of Agriculture. 2000. National organic program. Final rule: 7 Code of Federal Regulations, Part 205. USDA Agr. Mktg. Serv. 22 Jan. 2002. <http://www.ams.usda.gov/nop>.

van der Werf, E., J. Kariuki, and D.D. Onduru. 1997. Methodological issues in comparative agro-economic on-farm research assessments of organic versus conventional farming techniques. Biol. Agr. Hort. 14:53-69.

Vogtmann, H. 1990. Research structure in biological farming: General view, justification, development, p. 41-47. In: Biological farming in Europe. Reg. Euro. Union Office Tech. Ser. 12. Proc. Expert Consultation. FAO, Bern, Switzerland.

Walz, E. 1999. Final results of the $3^{\text {rd }}$ biennial national organic farming survey. Org. Farming Res. Found., Santa Cruz, Calif.

Wander, M.M., S.J. Traina, B.R. Stinner, and S.E. Peters. 1994. Organic and conventional management effects on biologically active soil organic matter pools. Soil Sci. Soc. Amer. J. 58:1130-1139.

Wang, S.H.L., V.I. Lohr, and D.L. Coffey. 1984. Spent mushroom compost as a soil amendment for vegetables. J. Amer. Soc. Hort. Sci. 109:698-702.

Zerger, U. and H. Bossel. 1994. Comparative analysis of future development paths for agricultural production systems in Germany, p. 317-327. In: P. Midmore and N.H. Lampkin (eds.). The economics of organic farming: An international perspective. CAB Intl., Wallingford, U.K. 